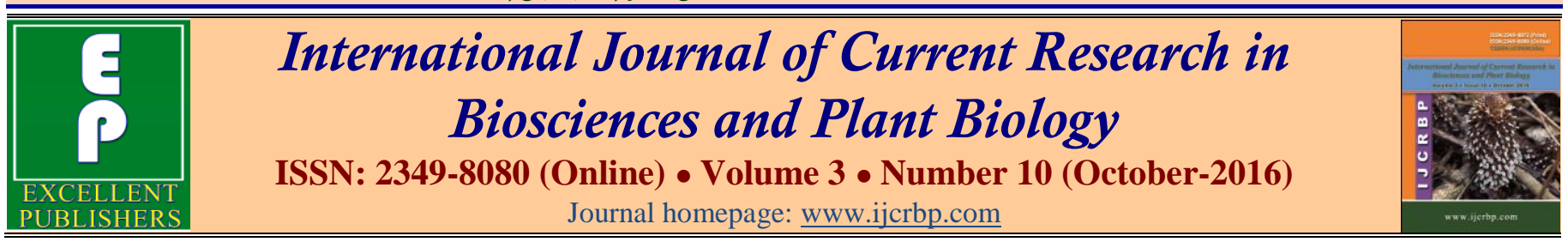

Original Research Article

doi: http://dx.doi.org/10.20546/ijcrbp.2016.310.023

\title{
In Vitro Evaluation of Antimicrobial Activity of Chaetomorpha antennina against Biofilm and Beta Lactamase Producing Food Isolates
}

\author{
S. Shanmugapriya* and A. Rajendiran
}

Department of Zoology, Arignar Anna Government Arts College, Musiri-621 201, Tiruchirappalli Dt., Tamil Nadu, India

*Corresponding author.

\begin{abstract}
A bstract
This study evaluates the antibacterial activity of methanol and acetone extracts of Chaetomorpha antennina collected from Mandapam area, Rameshwaram Dt. The algal extracts were tested for their antibacterial activity against multidrug resistant, biofilm and beta lactamase producing isolates of Gram positive and Gram negative bacteria. The greatest antimicrobial activity was obtained when using methanol extract. Among the 6 bacterial genera, Enterococcus faecalis and Klebsiella pneumoniae were highly suppressed and E. coli was resistant to both extracts. This study was proved Chaetomorpha antennina had antimicrobial activity against food pathogens. Further research may help to find the bioactive compounds from algae.
\end{abstract}

\section{Article Info}

Accepted: 04 October 2016

Available Online: 06 October 2016

Keywords

Antimicrobial activity

Biofilm

Beta lactamase

Chaetomorpha antennina

\section{Introduction}

Antibiotic resistance is a global public health problem in 16 the world, especially in developing countries. The infectious disease mortality rate in India today is $\mathbf{4 1 6 . 7 5}$ per 100,000 persons. The overuse and inappropriate use of the drug were creating the resistance strain; this phenomenon was a greater threat in poorer nations than in richer ones.

Studies from WHO report have shown very high rates of resistance in bacteria such as Escherichia coli against antibiotics as cephalosporin and fluoroquinolones, Klebsiella pneumoniae against cephalosporin and carbapenems, Staphylococcus aureus against methicillin. These isolates causing infection was untreatable because its causative agent has been found to be resistant to cephalosporin as well as carbapenems due to extended spectrum $\beta$-lactamases (ESBL) mediated mechanism
(Bennett et al., 2010). In India and Pakistan, 95\% of adults were carrying bacteria that are resistant to $\beta$ lactam antibiotics (Reardon, 2014). Treatment of these drug-resistant organisms is a deep scientific worry. These antibiotics were mostly used for common infection and continue to be the prominent cause of resistance to $\beta$-lactam antibiotics. The repeated exposure of bacterial strains to a $\beta$-lactams has induced production of $\beta$ lactamases in these bacteria, this situation, expanding their activity even against the newly developed $\beta$-lactam antibiotics. These enzymes are also known as extendedspectrum $\beta$-lactamases (ESBLs) (Paterson and Bonomo, 2005). Therefore, alternative antimicrobial strategies are urgently needed.

The natural antimicrobial substances have been recorded in marine environments. Among the marine organisms, the macro algae (seaweeds) occupy a special site as a source of beneficial substances which are active 
againstto bacteria, fungi, virus and cancer (Perez et al., 2016). Among the macroalgae, Chlorophyceae members have a number of beneficial activities such as antioxidant, anticancer, antibacterial and antifungal, especially, Chaetomorpha antennina has potential activity (Manchu et al., 2015). According to the literature review, no one studies the antimicrobial activity against ESBL producing isolates. This work aims to evaluate the antimicrobial activity of $C$. antennina extracts against ESBLs isolates and also find alternative drugs and promising source of pharmaceutical agents.

\section{Materials and methods}

\section{Seaweed collection and preparation}

C. antennina was collected from Mandapam, Rameshwaram district, Tamil Nadu, India. Collected algae were cleaned with seawater to remove impurities. The seaweeds were transported to the laboratory in sterile polythene bags. In the laboratory, samples were rinsed with tap water and were shade dried, cut into small pieces and powdered in a mixer grinder.

Five grams of each powdered sample were soaked in 40 $\mathrm{ml}$ of the solvent for three days. Remain extracts were filtered and concentrated in a rotatory evaporator at $35^{\circ} \mathrm{C}$. The residual water was removed with a vacuum pump. The weighted crude extracts were suspended in the dimethyl sulfoxide (DMSO) to a final concentration of $50 \mathrm{mg} / \mathrm{ml}$ and stored in a refrigerator (El Shafay et al., 2016).

\section{Isolation of food pathogens}

Five types of meat samples were collected from the local market. Samples were homogenized using a meat grinder under aseptic conditions and were inoculated on following selective media such as EMB, MSA, SS agar, Cetramide, MacConkey and chromogenic media. After 24 hrs the morphological characters were observed. Bacterial identification was conducted by standard biochemical methods (Collee et al., 1996).

\section{Antibiotic susceptibility testing}

The antimicrobial susceptibility of the collected bacteria was assessed using the modified Kirby-Bauer disk diffusion method. Following antibiotics were used for this study. Gentamycin, cefotaxime, ceftriaxone, erythromycin, kanamycin, penicillin, bacitracin, ampicillin, tetracyclin and amoxicillin. The antibiotic disks were then applied to the prepared plates and incubated at $37^{\circ} \mathrm{C}$ for $18 \mathrm{hrs}$ then the diameter of the growth inhibition zones was measured.

\section{Isolation of biofilm producing isolates}

Brain heart infusion agar supplemented with $5 \%$ sucrose and Congo red $(0.08 \mathrm{~g} / \mathrm{l})$ was prepared and autoclaved at $121^{\circ} \mathrm{C}$ for 15 minutes. The food isolates were inoculated and incubated aerobically at $35^{\circ} \mathrm{C}$ for to $48 \mathrm{hrs}$. Biofilm production was indicated by black colonies with a dry crystalline consistency whereas biofilm non-producers remain pink, though occasional darkening at the center of the colony was observed (Suganya et al., 2014).

\section{Assay for beta-lactamase production}

Beta-lactamase production was assayed using the method of Lateef (2004). Broth culture of the test organism was spot inoculated on to Mueller-Hinton agar and 1\% starch and then incubated overnight at $37^{\circ} \mathrm{C}$. The plates were then flooded with sterile phosphate buffered saline containing potassium iodide, iodine and penicillin. Betalactamase production was assessed by the presence of clear colorless zones around the bacterial growth. All the bacterial isolates were tested for the production of betalactamases.

\section{Determination antibacterial activity}

Twenty ml of sterilized Mueller Hinton agar (MHA) was poured into each Petri plate $(90 \mathrm{~mm}$ diameter) and allowed to solidify. The plates were incubated with freshly prepared inoculums which were swabbed over the entire surface of the medium, rotating the plate degrees after each application by using a sterile cotton swab, to ensure the spread of the tested microbes on the surface of the plate completely. Inoculums were 108 $\mathrm{CFU} / \mathrm{ml}$ of bacteria. One well of $6 \mathrm{~mm}$ diameter was bored in the medium of each plate with the help of sterile cork-borer. Different concentration of extract was filled each well with the help of micropipette. Gentamycin $(5 \mu \mathrm{g} / \mathrm{ml})$ was used as positive control.

\section{Results and discussion}

The number of mechanisms of resistance has been described; the most common being enzymatic inactivation of the ATB molecule, altered target sites, decreased uptake and/or increased efflux of the antimicrobial agents. $\beta$-lactamases are a major resistance 
mechanism against the widely used $\beta$-lactam antibiotics, which target penicillin-binding proteins (PBPs) involved in bacterial cell wall synthesis. $\beta$-lactamase enzymes inactivate $\beta$-lactam antibiotics, by hydrolyzing their $\beta$ lactam ring essential to antibiotic function (Khan et al., 2014).

In this study, of the total 17 isolates subjected to antimicrobial susceptibility test, $100 \%, 89 \%, 83.2 \%$ and
$75 \%$ exhibited resistance to ampicillin, amoxicillin, penicillin, tetracycline and bacitracin in that order. The worrying aspect of the current study is that $(29.4 \%)$ of the isolates were resistant to antibiotics and single isolate resistance to antibiotics (Fig. 1). Among the 6 types of bacterial isolates, highest resistance was observed in E. coli $(70 \%)$, Salmonella species $(65 \%)$, E. faecalis $(63.3 \%)$ S. aureus $(60 \%), K$. pneumoniae $(57 \%)$ and P. aeruginosa (53.3\%) (Fig. 2).

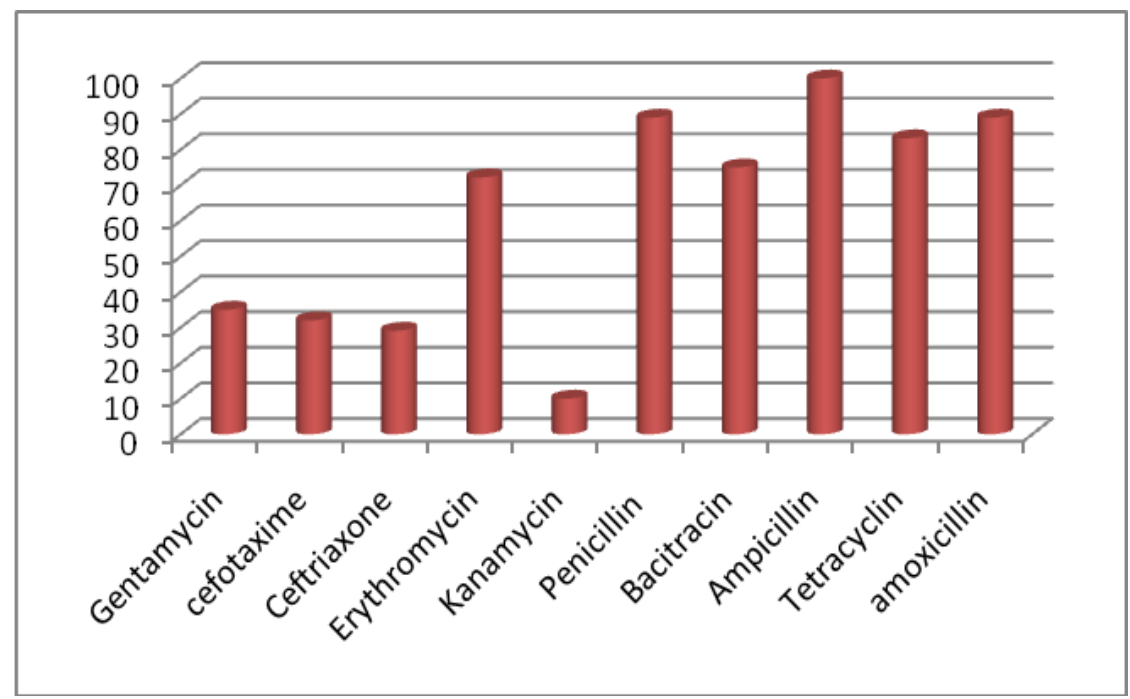

Fig. 1: Antibiotic resistance patterns of food isolates.

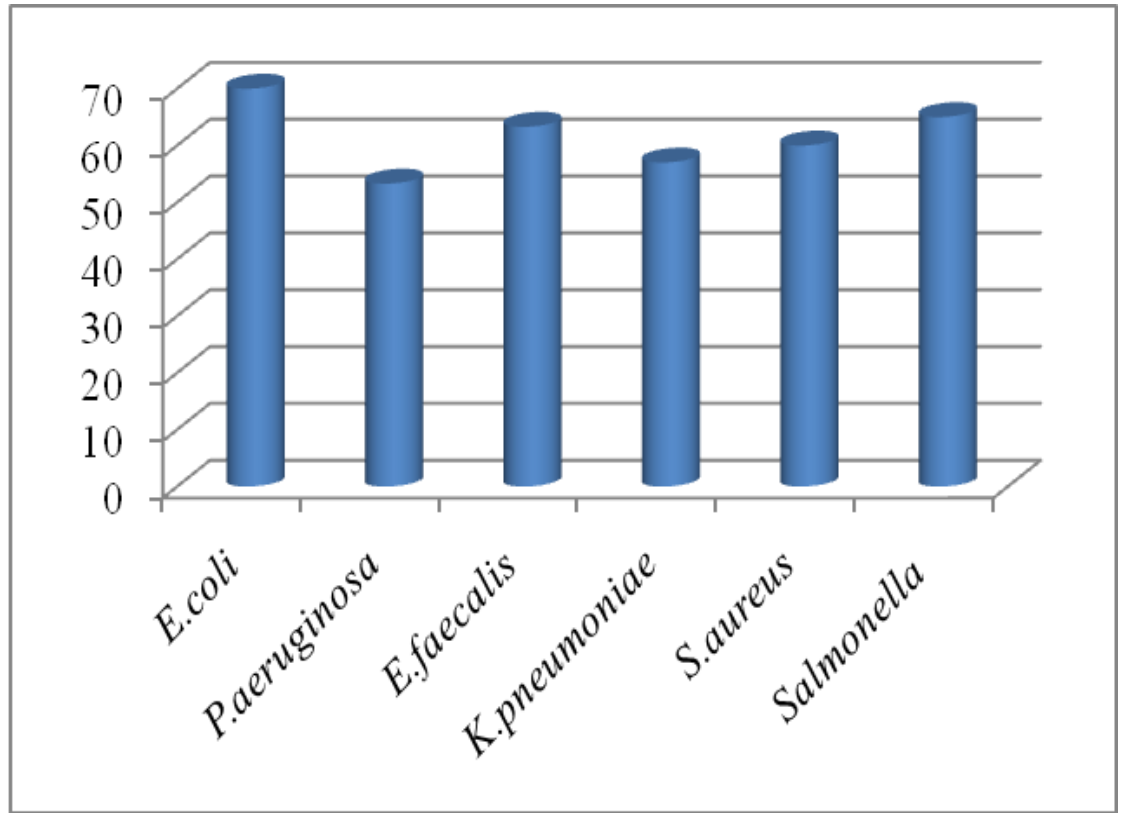

Fig. 2: Percentage of antibiotic resistance in food isolates.

Furthermore, antibiotic resistance is due to the formation of biofilm by microorganisms, this biofilm formation enhanced resistance to antibiotics and other environmental stresses (Branda et al., 2005). Biofilm promotes bacterial persistence by resisting, antibiotic treatment and host immune responses (Namasivayam et al., 2012). Hence, urgently need new ways to deal with pathogens, especially ESBL and Biofilm producing 
isolates. Against a backdrop of this information, our investigation was focused on biological derivatives, because the biological nature of these compounds involves reduced side effects compared to conventional chemical agents. This study was considered to evaluate the antibacterial potential of $C$. antennina against six clinical bacterial isolates. Table 1 reveals the algal extracts prepared with methanol and acetone had active principles that could inhibit the growth of the pathogenic bacteria tested.

Table 1. Antimicrobial activity of $C$. antennina.

\begin{tabular}{|c|c|c|c|c|c|}
\hline \multirow[t]{2}{*}{ Name of the isolates } & \multicolumn{2}{|c|}{$\begin{array}{l}\text { Methanol extract } \\
\text { (Result in } \mathrm{mm} \text { ) }\end{array}$} & \multicolumn{2}{|c|}{$\begin{array}{l}\text { Acetone extract } \\
\text { (Result in } \mathbf{~ m m})\end{array}$} & \multirow[t]{2}{*}{ Gentamycin } \\
\hline & $50 \mu g$ & $100 \mu \mathrm{g}$ & $50 \mu \mathrm{g}$ & $100 \mu \mathrm{g}$ & \\
\hline E. coli & - & - & - & - & 10 \\
\hline P. aeruginosa & 9 & 12 & - & - & - \\
\hline E. faecalis & 10 & 16 & 13 & 15 & - \\
\hline
\end{tabular}

The methanol and acetone extract of $C$. antennina of $2 \mathrm{mg}$ and $4 \mathrm{mg}$ concentrations did not provoke a zone of inhibition against $E$. coli. In the case of methanol extract, the zone of inhibition range from $9 \mathrm{~mm}$ from $16 \mathrm{~mm}$ among the six types of genera, highly suppressed by $K$. pneumoniae and E. faecalis. This extract had less inhibitory effect against $P$. aeruginosa isolate. Among the 6 genera, 4 of were suppressed when using acetone extract and zone of inhibition ranged from $9 \mathrm{~mm}$ to $15 \mathrm{~mm}$ and which extract was highly suppressed to $E$. faecalis and lowest inhibition activity against to $S$. aureus. Sivakumar and Safhi (2013) reported that $50 \mu \mathrm{g}$ of petroleum ether extract of $C$. antennina showed the zone of inhibition ranged between 6 to $25 \mathrm{~mm}$ against the tested organisms. Recently, Jolly and Iyer (2015) reported methanol extract of $C$. antennina was showed low activity against $E$. coli. The present study was contrary to Premalatha et al. (2011), who observed highest antimicrobial activity when using methanol extract of $C$. antennina.

From the overall studies, 5 isolates were inhibited by using methanol extract compared with acetone extract. The $C$. antennina showed more or less equal zone of inhibition or slightly greater against some pathogens when compared with positive control gentamycin impregnated positive control discs. Antibacterial activities of algal extracts depend on algal species, the efficiency of the extraction method and concentration of the extract. Previous reports on the most effective solvent for the extraction of antimicrobials have been varied; Kolanjinathan et al. (2009) selected methanol as a solvent for extraction of antimicrobial compounds from seaweeds. Shanmughapriya et al. (2008) found methanol: toluene (3:1) as the best solvent for extracting antimicrobials from fresh algae. In this current study, superlative activity was observed when using methanol extract. This was agreed with the previous study of Manivannan et al. (2011). They were found highest antibacterial activity when they screened brown algae with methanol. A similar result was found in present study. This antimicrobial activity also depends on the habitat and the season of algal collection. Although a variety of solvents have been employed in screening seaweeds for antimicrobial activity, it is still uncertain what kinds of solvent is the most effective and suitable for extraction of seaweeds.

From these preliminary investigations, the algal extract was activity against to biofilm and beta-lactamase producing isolates. The present study was conducted to develop newer lead for better and safer antimicrobial agents from seaweed. Further studies are needed to identify the pure component and establish the exact mechanism of the seaweed extract.

\section{Conflict of interest statement}

Authors declare that they have no conflict of interest.

\section{References}

Bennett, J.W., Robertson, J.L., Hospenthal, D.R., Wolf, S.E., Chung, K.K., Mende, K., Murray, C.K., 2010. Impact of extended spectrum beta-lactamase producing Klebsiella pneumoniae infections in severely burned patients. J. Am. Coll. Surg. 211(3), 391-399.

Branda, S.S., Vik, A., Friedman, L., Kolter, R., 2005. Biofilms: The matrix revisited. Trends Microbiol. 13, 2026.

Collee, J., Fraser, G., Marmion, P., Simmons, A., 1996. Practical Medical Microbiology. $4^{\text {th }}$ Edn. Churchill Livingstone, New York. pp.413-416. 
El Shafay, S. M., Ali, S. S., El-Sheekh, M. M., 2016. Antimicrobial activity of some seaweeds species from Red sea, against multidrug resistant bacteria. Egypt. J. Aquatic Res. 42(1), 65-74.

Jolly, R.R., Iyer, P., 2015. Isolation, characterization and application of fucoidan from weeds. Int. J. Curr. Res. Biosci. Plant Biol. 2(7), 212-216.

Khan,S., Sallum, U.S., Zheng, X., Nau, G. J., Hasan, T., 2014. Rapid optical determination of $\beta$-lactamase and antibiotic activity. BMC Microbiol. 2014(14), 84.

Kolanjinathan, K., Ganesh, P., Govindarajan, M., 2009. Antibacterial activity of ethanol extracts of seaweeds against fish bacterial pathogens. Eur. Rev. Med. Pharmacol. Sci. 13, 173-177.

Lateef, A., 2004. The microbiology of a pharmaceutical effluent and its public health implications. World J. Microbiol. Biotechnol. 20, 167-171.

Manchu, N., Melpha, Y., Jeeva, S., Edwin James, J., 2015. Phytochemical analysis and antibacterial activity of Chaetomorpha antennina from Rasthacaud coast, Tamil Nadu, India. World J. Pharmaceut. Res. 4(3), 1340-1351.

Manivannan, K., Karthikai Devi, G., Anantharaman, P., Balasubramanian, T., 2011. Antimicrobial potential of selected brown seaweeds from Vedalai coastal waters, Gulf of Mannar. Asian Pac. J. Trop. Biomed. 1(2), 114120.

Namasivayam, S.K.R., Preethi, M., Bharani, A.R.S., Robin, G., Latha, B., 2012. Biofilm inhibitory effect of silver nanoparticles coated catheter against Staphylococcus aureus and evaluation of its synergistic effects with antibiotics. Int. J. Biol. Pharm. Res. 3, 259-265.

Paterson, D.L., Bonomo, R. A., 2005. Extended-spectrum beta-lactamases: A clinical update. Clin. Microbiol. Rev. 18, 657-686.

Perez, M. J., Falque, E., Domínguez, H., 2016. Antimicrobial action of compounds from marine seaweed. Mar. Drugs. 14(3), 52.

Premalatha, M., Dhasarathan, P., Theriappan, P., 2011. Phytochemical characterization and antimicrobial efficiency of seaweed samples Ulva fasciata and Chaetomorpha antennina. Int. J. Pharma Biosci. 2(1), 288-293.

Reardon, S., 2014. Antibiotic resistance sweeping developing world. Nature. 509(8), 141-142.

Shanmughapriya, S., Manilal, A., Sujith, S., Selvin, J., Kiran, G.S., Natarajaseenivasan, K., 2008. Antimicrobial activity of seaweeds extracts against multiresistant pathogens. Ann. Microbiol. 58(3), 535- 541.

Sivakumar, S.M., Safhi, M. M., 2013. Isolation and screening of bioactive principle from Chaetomorpha antennina against certain bacterial strains. Saudi Pharmaceut. J. 21, 119-121.

Suganya, A., Jegadeeshkumar, D., Ravi, D., 2014. Antibacterial activity of fruit extracts of Syzygium cumini against extended spectrum $\beta$-lactamase producing diarrheal isolates of E. coli. Int. J. Adv. Interdis. Res. 1(11), 13-16.

\section{How to cite this article:}

Shanmugapriya, S., Rajendiran, A., 2016. In vitro evaluation of antimicrobial activity of Chaetomorpha antennina against biofilm and beta lactamase producing food isolates. Int. J. Curr. Res. Biosci. Plant Biol. 3(10), 179-183 doi: http://dx.doi.org/10.20546/ijcrbp.2016.310.023 